Article

\title{
Ecosystem Services as a Boundary Concept: Arguments from Social Ecology
}

\author{
Christian Schleyer ${ }^{1, *}$, Alexandra Lux ${ }^{2,3}$, Marion Mehring ${ }^{3,4}$ and Christoph Görg ${ }^{5}$ \\ 1 Section of International Agricultural Policy and Environmental Governance, University of Kassel, \\ 37213 Witzenhausen, Germany \\ 2 ISOE-Institute for Social-Ecological Research, Transdisciplinary Methods and Concepts, \\ 60486 Frankfurt/M., Germany; lux@isoe.de \\ 3 Senckenberg Biodiversity and Climate Research Centre (BiK-F), 60325 Frankfurt/M., Germany; \\ mehring@isoe.de \\ 4 ISOE-Institute for Social-Ecological Research, Biodiversity and People, 60486 Frankfurt/M., Germany \\ 5 Institute of Social Ecology, 1070 Vienna, Alpen-Adria University, 9020 Klagenfurt, Austria; \\ christoph.goerg@aau.at \\ * Correspondence: schleyer@uni-kassel.de; Tel.: +49-179-11-66-474
}

Received: 4 February 2017; Accepted: 16 June 2017; Published: 26 June 2017

\begin{abstract}
Ecosystem services (ES) are defined as the interdependencies between society and nature. Despite several years of conceptual discussions, some challenges of the ES concept are far from being resolved. In particular, the usefulness of the concept for nature protection is questioned, and a strong critique is expressed concerning its contribution towards the neoliberal commodification of nature. This paper argues that these challenges can be addressed by dealing more carefully with ES as a boundary concept between different disciplines and between science and society. ES are neither about nature nor about human wellbeing, but about the mutual dependencies between nature and human wellbeing. These mutual interdependencies, however, create tensions and contradictions that manifest themselves in the boundary negotiations between different scientific disciplines and between science and society. This paper shows that approaches from Social Ecology can address these boundary negotiations and the power relations involved more explicitly. Finally, this implies the urgent need for more inter- and transdisciplinary collaboration in ES research. We conclude (1) that the social-ecological nature of ES must be elaborated more carefully while explicitly focussing on the interdependencies between nature and society; (2) to better implement inter- and transdisciplinary methods into ES research; and (3) that such ES research can-and to some extent already does-substantially enhance international research programmes such as Future Earth.
\end{abstract}

Keywords: ecosystem services; social-ecological systems; social ecology; transdisciplinary research; interdisciplinary research; colonisation; boundary concept

\section{Introduction}

The concept of Ecosystem Services (ES) has been created to address the interactions between nature and society. It describes the relevance of ecosystem functions for human wellbeing [1]. Moreover, the concept raises high expectations to inform decision-making on the interrelation and dependencies between societal and natural processes. Its scope is very broad, ranging from agricultural products to climate regulation and cultural services. Thus, it is dedicated to showcase trade-offs across various economic sectors, different fields of human wellbeing (from health and food to aesthetic perceptions) and related policy fields, and to reveal synergies among them while taking ecological limits seriously.

What is not yet adequately addressed is the specific character of the ES concept at the interplay of societal and natural processes (see [2]). The concept is neither about ecosystems, i.e., on biophysical 
processes as an object of natural science research, nor is it about the economic value and the goods provided by ecosystems, i.e., on socioeconomic valuations or cultural perceptions, analysed by economics and social sciences. Ecosystem services are about how both processes mutually depend on each other, i.e., about the interdependencies between society and nature. Such mutual interdependencies require a specific inter- and transdisciplinary research, which can be provided by Social Ecology [3-5].

The main objective of this article is to further the social-ecological perspective in order to strengthen the ES concept in the context of inter- and transdisciplinary research. In Section 2, we elaborate from a perspective of Social Ecology on what is meant by the notion that the ES concept is inherently social-ecological in nature. From there, we deal with it as a boundary concept between different disciplines and between science and society. An analysis from a social-ecological perspective serves also as a better starting point to explain the expectations of the concept and its application. For this reason, the theoretical underpinnings and practical challenges of ES as a boundary concept are introduced (Section 3). For implementing this social-ecological perspective, interdisciplinary (Section 4) and transdisciplinary (Section 5) collaboration are needed, focussing on the relationship between ES and the colonisation of nature. Finally, we showcase the requirements and implications for an application of the concept in social-ecological research.

\section{The Ecosystem Services Concept from a Perspective of Social Ecology}

After several years of research and conceptual discussions, there is still considerable disagreement in ES research and practice. Until now, several gaps of the ES concept have been scrutinised, most of them related to its anthropocentric and economic impetus (e.g., [6]). Much of the criticism calls for improvements in terminologies [7,8] and methods [9]. Whether the debate on ES deals with an agreed classification is also scrutinised [10-12], and there are calls for a more participatory approach towards ES research that takes issues of social perceptions and co-production seriously, especially concerning cultural services [13-15]. With respect to valuation, application of the ES concept is often criticised for its bias towards monetary valuation and the commodification of nature [16-18].

Starting from Social Ecology, however, offers a slightly different perspective on the concept. It emphasises that the ES concept is neither about ecosystems nor about societal goods and human wellbeing solely, but about the interdependencies between human wellbeing and nature $[2,19,20]$. Some of the challenges addressed in the current debates are related to the question of how to deal with this social-ecological character of ES. For example, research on ES assumes, usually implicitly, that ES are provided by ecosystems as natural processes independent from human influences. This assumption, however, ignores the role of human interventions (labour, technology, and capital) in improving the supply of ES (in particular, agricultural goods, but also forest products and cultural or regulating services) by transforming 'natural ecosystems' into human-modified cultural landscapes [21-25]. While one study shows that humans indeed often contribute to the maintenance and enhancement of ecosystems [26], another emphasises "that increased use of manufactured and financial capital might deliver higher quantities of ecosystem services in the short-term but is often associated to several trade-offs in space and time" [27] (p. 271). Such interventions, in reverse, are captured by the concept of colonisation, an important concept of Social Ecology [23,28] (see Section 4) and offer a different starting point for an analysis of the capacity of ecosystems to contribute to human wellbeing. Thus, a more careful treatment of this social-ecological character may substantively improve the application of the ES concept. In this regard, the paper builds upon inter- and transdisciplinary research and conceptual discussions conducted at the Institute of Social Ecology (SEC) in Vienna (Austria) and the ISOE-Institute for Social-Ecological Research in Frankfurt/Main (Germany) (see [5] in this issue).

The concrete potential for an improved uptake of the ES concept is shown in this paper by discussing fundamental issues of the scientific conceptualisation of ES at the boundaries between different scientific disciplines and between science and society. We emphasise that approaches from Social Ecology are well-suited to address the related boundary negotiations and the power 
relations involved. For this reason, we argue in this paper that inter- and transdisciplinary research is needed to improve the societal relevance of the ES concept and the link to human wellbeing. We also reflect on the potential discrepancy between a concept that inherently depends on inter- and transdisciplinary research approaches and 'thinking', as well as respective forms of collaboration, and their practical application.

\section{Ecosystem Services as a Boundary Concept: Potential and Application}

The ES concept can be considered as a boundary concept (e.g., [19,29,30]). A boundary concept enables researchers from different disciplines, policy makers, and other stakeholders to develop a common language [31], and respectively integrate and derive knowledge relevant to their field [32]. At the same time, the exact meaning and conceptualisation of such a boundary concept is contested both between different scientific disciplines, and between science and society; this will be determined in boundary negotiations [33]. Thus, the vagueness of the ES concept (e.g., [6]) is both a blessing and a curse. On the one hand, the vagueness is the outcome of continuous, complex, and demanding negotiations (boundary work) about, for example, how the ES concept is defined, how implementation and application is interpreted, which foci are set, and which tools are used. With respect to policy and decision-making, these negotiations are not only a scientific exercise but-to some degree-also linked to political or societal interests [34-36]. Moreover, due to its nature as a boundary concept, knowledge claims concerning ES from different scientific disciplines are linked to certain fields of policy-making and may potentially conflict with other fields (e.g., conservation biology linked to nature protection conflicts vs. agricultural research which emphasises provisioning services $[37,38])$. These differences may also cause ambiguities and tensions in the core meaning of the concept, concerning, for example, the strengths and limits of economic valuation methods (including the debate on how to define, quantify, and value ES [10-12]) or the need for integrated approaches of monetary and non-monetary valuation methods [39-41]. These tensions and ambiguities may also refer to the objectives involved (e.g., its anthropocentric bias) or different strategies to define the building blocks of the conceptual framework. The latter become apparent when comparing, for example, the steps and arrows of the Cascade Model in [12] (see Figure 1) with the Stairways Model in [21] (see Figure 2). Similarly, scientists, policy makers, and other stakeholders may impose very different normative values and their respective key components on application of the ES concept: sustainability (ecological, economic, social); justice (distributional, procedural, and recognition); and diversity (biological, cultural/linguistic, and institutional).

Looking back into the history of the ES concept, these boundary negotiations can be understood as major reasons for some conceptual ambiguities and the related scientific debates. The ES concept was revisited and elaborated further in the context of the Millennium Ecosystem Assessment [1], later during the international TEEB (The Economics of Ecosystems and Biodiversity) initiative [42], and in the IPBES (Intergovernmental Science-Policy Platform on Biodiversity and Ecosystem Services) context [43] and beyond. Over time, expectations were raised that the concept may improve the interface between science and society and the relevance of science for policy-making and the management of ecosystems [19]. Indeed, as pointed out in one study [32], the language of ES has often been deliberately used by scientists and environmentalists with the precise aim of tailoring ecological knowledge to users, particularly policy-makers and politicians. As those users often have economic and social concerns as their main priority, economic language is perceived as a powerful tool to convince policy- and other decision-makers outside the environmental policy domain. Used in this context, it is expected that the ES concept may substantially inform policy-makers and other stakeholders when drafting or revising policies.

From the beginning, however, there were concerns, in particular, about the limits of the economic 'language'. For example, the TEEB-approach failed to produce one single (economic) number to demonstrate the global relevance of biodiversity and ecosystem services. By contrast, it emphasised the need to contextualise the link between science and policy, and to develop specific approaches 
for certain audiences, for example, national and international policy-makers, but also regional and local policy-makers and businesses (see teebweb.org). During the negotiations of IPBES, the economic bias of the ES concept, and its application, became a matter of political debate and scientific concern. Because some countries challenged the ES concept as a perceived tool for the commodification of nature, the conceptual framework developed within IPBES explicitly emphasizes different and conflicting worldviews and asks for a translation between them [43]. Therefore, valuation of ecosystems and their services is increasingly recognised as a contested issue which needs careful consideration, due to the nature of ecosystem services as a boundary concept.

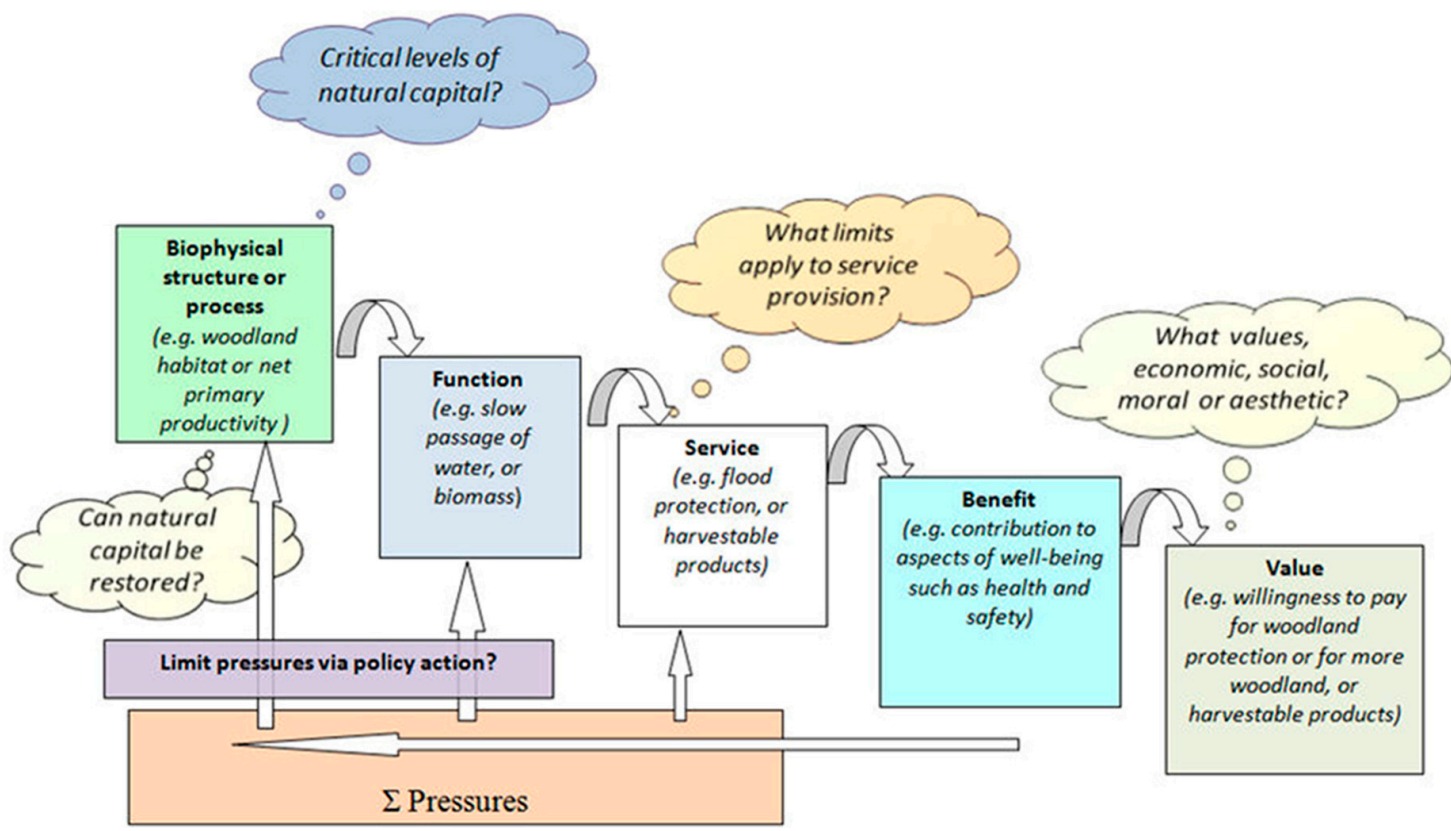

Figure 1. The ecosystem services Cascade Model [12].

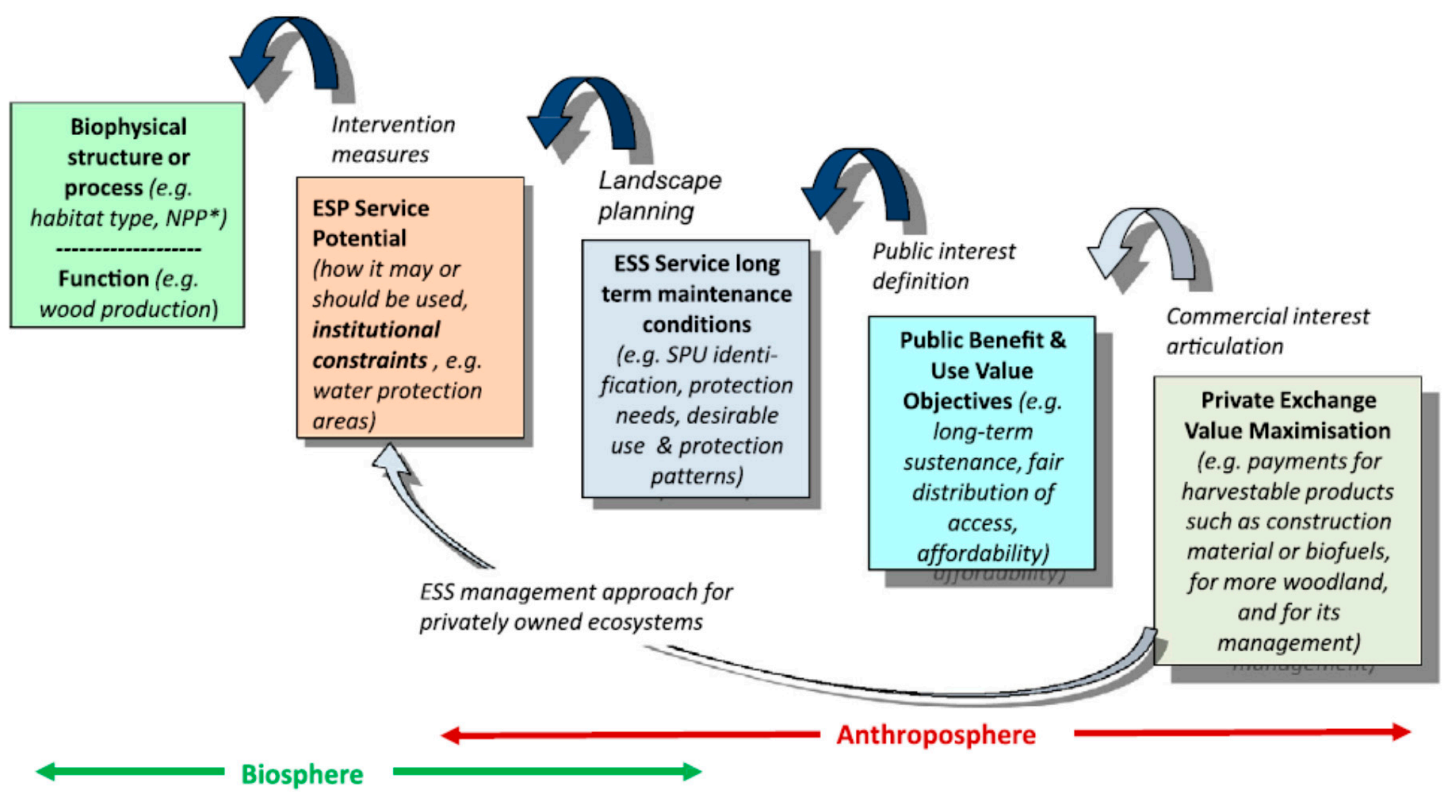

Figure 2. The ecosystem services Cascade Model, as adapted by [21], turning the cascade into stairways. $\mathrm{NPP}=$ Net Primary Production; ESP = Ecosystem Service Potential; ESS = Ecosystem Service. 
Input from different scientific disciplines and non-scientific knowledge must be incorporated, and different purposes and different kinds of valuation must be considered. Further, different kinds of purpose may include different kinds of application (e.g., awareness raising, policy negotiations for mainstreaming ES, or monitoring of ecosystems and their state). Within these purposes, differing cultural perceptions and different kinds of valuation must be reflected carefully, especially concerning economic valuation tools within certain cultural contexts [14]. Within certain contexts, monetary values may not be perceived as legitimised measures or indicators (e.g., the economic value of a certain piece of land or a tree which is considered as sacred) or even insignificant (see [22] for an example resulting from extensive field work); these efforts may not be perceived as helpful, and instead, as undermining the foundations of certain cultures. Thus, to realise its potential as a tool at the interface between science, general society, and policy-making, the boundary work, which is often concealed within the knowledge claims of different disciplines, must be revealed and reflected carefully. More precisely, inter- and transdisciplinary research on ES should avoid oversimplified assumptions about the application of ecosystem valuation, and requires participatory mechanisms to integrate the often very diverse value attributions of stakeholders towards various ecosystem services [21].

After many years of discussion in the scientific domain, and a multitude of attempts to implement the ES concept (or parts of it) in practice, developing and establishing such an integrated approach of inter- and transdisciplinary research remains challenging; many investigations have failed to integrate biophysical and socio-cultural dimensions adequately, or suffered from inappropriate design of stakeholder involvement-if these challenges were addressed at all $([14,41,44])$. Further, applying the ES concept on the ground comes along with very concrete and non-trivial knowledge needs on the part of different stakeholders, including methods and tools for ES assessment and valuation and for dealing with trade-offs made explicit in the process $[31,45,46]$.

In summary, following the approach of ES as a boundary concept, it is possible to better understand the controversies and debates surrounding this concept both within science and between science and practice. This understanding is an important precondition for improving the applicability of the ES concept and its ability to address societal issues $[47,48]$. At the same time, the concept and its vagueness offer opportunities to address, and to some extent integrate, the perspectives of several policy fields while dealing with respective differences in meaning and definition. Against this background, once again, inter- and transdisciplinarity as integrated research modes come to the fore. They support inclusive processes that, inter alia, allow to reveal contested assumptions on the sustainable use of ecosystem services.

\section{Social-Ecological Nature of Ecosystem Services: Challenges for Interdisciplinary Collaboration}

The need for interdisciplinary collaboration on ES is widely acknowledged, at least in principle. The concept was developed over the last decade as a result of strict interdisciplinary collaboration between natural scientists, mostly from ecology, and social scientists, in particular from ecological economics (for the history of the concept, refer to [49]). It is no coincidence that the most prominently involved subdisciplines are those which are heterodoxies, or at least are open to cross-disciplinary collaboration, for example, ecological economics and conservation biology. Nevertheless, there is concern from several sides that interdisciplinary collaboration remains challenging. For example, Norgaard warned several years ago that the use of the ES concept may move from an eye-opener to a complexity blinder [41], when ignoring the huge conceptual challenges involved. Other challenges are related to certain parts of the ES concept, such as the intangible values of cultural services [14] and the tendency to express all kinds of values only, or preferably, in monetary terms [40]. For the purpose of this article, one challenge is particularly important and is often concealed in ES research: the social-ecological nature of ES, that represents a specific challenge for interdisciplinary research.

One of the major challenges for addressing the social-ecological nature of ES is the assumption that ES are provided directly by ecosystem functions, as suggested in the so-called ES Cascade Model developed by [12]. The Common International Classification of Ecosystem Services (CICES) was 
developed to provide a basis for an agreed classification system [50], and to avoid duplication and misrepresentation; the Cascade Model describes ES as a rather linear flow from ecosystems to humans. Biophysical structures and processes generate ecosystem functions, which in turn provide ES to humans benefitting from them, depending on their values (see Figure 1). Feed-back loops are included in this cascade, as pressures in ecosystems may induce policy responses. Moreover, several knowledge gaps are highlighted concerning the critical levels of ES provisioning, the restoration capacity of ecosystems, and the different kinds of valuation approaches involved, within and beyond economic values. Yet, the basic idea is a linear delivery of services and benefits, based on the capacity of ecosystems and their biophysical properties.

This basic idea can be challenged by at least two considerations: first, the very nature of ecosystems in most parts of the world, which are mostly culturally transformed landscapes, and which depend in their delivery of services very much on the modification through human activities [24,25]; and, second, the very nature of benefits, which in most cases need interventions in the form of labour and technology [22]. At first glance, the first argument does not seem to be decisive, as the same modification of ES delivery is also addressed by the feed-back loop of the Cascade Model. The difference, however, is characterised by the notion that the modifications of landscapes manifest themselves not only as pressures, but also as the supply of both provisioning services (e.g., production of food and feed, or provision of shelter) and regulating services (e.g., flood protection) increasing or appearing in the first place due to modification of a concrete landscape. Thus, maintaining the resulting landscape depended—and still depends—on human labour and technology, and the input of other resources such as fertilisers and knowledge. From a social-ecological perspective, it thus depends on continuing what we call the colonisation of nature [51].

The term 'colonisation of nature' was introduced to analyse the human interventions into ecosystems as part of the Neolithic revolution and the introduction of agriculture [40]. From this time onwards, the productivity of ecosystems increased significantly as did the proportion that humans appropriate from the net primary production of ecosystems. This is measured by the HANPP-index (Human Appropriation of Net Primary Production), the amount of Net Primary Production (NPP) used by societies. More precisely, "the HANPP indicator tells about how much of the potentially available annual plant biomass production (NPP) is appropriated through human colonizing interventions, through deliberate changes of the land cover (for example the conversion of pristine forest to grassland or arable land, or the sealing of soils by construction of cities and roads), and/or through harvest" [28] (p. 40). HANPP and embodied HANPP (eHanpp) in certain products such as food and feed stuff represents not only an important indicator for the relevance of 'nature' for societies, but also the other way around-for the constraints of this appropriation in the overall productivity of ecosystems [52]. As the colonisation of certain ecosystems differs due to the actual amount of technology and labour that certain societies are able to apply, it offers also a starting point for the analysis of the consequences of land use (changes) in ecological and social terms. Global inequalities as much as ecological consequences are closely linked, for example, to the amount of NPP in certain regions that are used or that can be used for beef production or other goals such as climate regulation.

From the perspective of Social Ecology, the interlinkages between ecosystems and benefits, or between nature and society, are conceptualised in a different way. The term 'colonisation of nature' clearly denotes "the intended and sustained transformation of natural systems, by means of organized social interventions, for the purpose of improving their utility for society. [ . . . ] A colonizing intervention must both be causally effective in changing some biophysical condition; it must make a difference in the world of matter. Likewise, it must be culturally conceived of, organized and monitored; it must, 'make sense' in the world of communication" [53] (p. 234). This concept acknowledges that the impact of societies on nature does not always undermine the functional requirements of ecosystems, as assumed in many nature conservation approaches, but often increases the capacity of an ecosystem for service provision. This does not mean, however, to ignore critical levels or constraints in the appropriation of nature. First, it denotes the dependencies of societies on ecosystems and the need to invest labour, resources, and money in 
their functioning. Moreover, limits exist, either in terms of available NPP or in terms of the loss of biodiversity and other negative side effects resulting from certain forms of appropriation (e.g., the use of fertilisers resulting in eutrophication of rivers and lakes). The former can be analysed using the HANPP-approach, whereas the latter needs additional analysis. As the original Cascade Model indicates, these questions can be addressed by the ES concept in general, but currently represent a major gap in research. In particular, the relationship between biodiversity loss and ES provision needs further investigation [54].

In addition, the work on 'social-ecological dynamics of ES' [2] point to a functional relation between ES provision and demand by society: nature and society exert mutual influence. A study from the Socotra Archipelago (Yemen) clearly illustrates that the provision of key ES (here: fish biomass for food production and household economies) is significantly correlated with the monsoon patterns, and consequently, with the fishing behaviour of the local communities. This seasonality in ES provision triggers complex adaption of local livelihood strategies. The local people adapted to this variation by, for example, developing trading activities with people from the island interior [2]. This study shows that the relation between ES and societal benefit cannot be explained by the Cascade Model [12] where ES only flow to society. It is rather the interlinkages-and in this case the dependency between ecosystems and benefits-that matter.

Another point is related to the first challenge, that service provision needs ongoing societal interventions in form of money, labour, and technology. To further elaborate on this intervention, the authors of [21] modified the Cascade Model further and introduced the concept of Ecosystem Service Potentials (ESP). The authors also merged the ecosystem structures and components, and the ecosystem functions into one category of ecosystem properties, representing the biophysical basis of service provision (see Figure 2). They argue that neither are the potentials determined by the functions, nor can they be assessed by analysing the services only: ESP are generated in complex social processes (e.g., increased commodification of nature or struggles about local commons), and these processes determine the kinds of services ultimately realised, or not (e.g., the loss of regulating services). Describing the process in a stepwise manner, first, an ESP must be recognised and the services the system could potentially provide must be identified (the authors call this 'use-value attribution'). The mobilised ESP can then be either directly consumed, or marketed as commodities. Thus, the benefits provided are either non-monetary benefits or monetary ones [22].

The difference between these benefits is decisive in terms of the societal processes which govern the appropriation of nature and, thus, enable a better understanding of the societal processes involved. Use value is the precondition that any good or service fits to human needs and creates a benefit. It is clearly linked to certain cultural value systems (e.g., in terms of what is perceived as a food, but also to cultural services such as spiritual values). In reverse, monetary values in capitalist societies are governed by exchange relations established by the (world) market, and thus, tend to ignore the relevance of ecosystems and nature for the actual benefits they provide. (It is an empirical question whether regional markets, not linked to the world market, still exist. In any case they are always threatened by global markets.) Use values which stimulate the overuse of resources can, of course, undermine the functional requirements of ecosystems. However, monetary or exchange values tend to ignore the biophysical requirements of ecosystems categorically and, thus, create a contradiction also called the 'metabolic rift' of capitalist societies [55-57]. Thus, this contradiction is the underlying cause why capitalism tends to destroy the productivity of land and soil [58,59]: it is not the intervention into nature (i.e., the colonisation of nature) but a specific kind of intervention as institutionalised into the capitalist market system that must be addressed by response strategies [60].

\section{The Role of Integration in Ecosystem Services Research: The Need for a Transdisciplinary Approach}

The sections above show that integration as the main challenge of ES as a boundary concept appears in different ways, particularly: 
(a) integrating scientific disciplines, i.e., the existing disciplinary knowledge as well as their modes of knowledge generation (methodologies);

(b) integrating knowledge from different sources (scientific and non-scientific);

(c) integrating different purposes for applying the ES concept (from assessment and awareness raising to policy advice and support for decision-making-which may all come together in a specific project, see, for example, the TEEB-studies [42]);

(d) integrating different perceptions of ES (from 'nature's gifts' to commodities) by different actors in civil society, policy, science, etc.;

(e) integrating perspectives of different action fields when it comes to take note of trade-offs between ES and their use or their conservation; and

(f) integrating different types of knowledge such as system, orientation, and transformation knowledge [61] for each step of the ES models, either the Cascade or the Stairways Model, as each step involves highly political decisions (e.g., [35,36]. In particular, orientation knowledge (e.g., which ES should be protected?) and transformation knowledge (e.g., how can we achieve sustainable use of ES for everybody?) is needed (see also [29]).

The integration tasks are anything but trivial when it comes to analysing the state and (future) changes of ES, and developing options for their management. While coping with integration, the major critique of the ES concept becomes vital: addressing integration means, on the one hand, to practice boundary work on terminology, methods, value attributions, and so on. On the other hand, integration of different perceptions, perspectives, and ultimately, different knowledge systems, has to deal with the manifold relations between nature and society, as pointed out in Section 4.

If the aim of ES-related research is to produce results that are scientifically sound and informative for practitioners and stakeholders, it should be conducted in a problem-oriented, integrative, and target-oriented manner. In this regard, Hirsch Hadorn et al. [62] pointed out that these challenges cannot be fully covered by applied research approaches, when issues cross boundaries between disciplines and problem fields. Such complex issues can only be tackled with transdisciplinary approaches [61-63]. Thus, the potentials of a transdisciplinary research mode must also be considered in ES research that aims to understand the dynamic interrelations between biophysical structures, their perception as ES, and their translation into benefits and values.

Jahn and colleagues [61] (p. 8f.) state, that "Transdisciplinarity is a critical and self-reflexive research approach that relates societal with scientific problems; it produces new knowledge by integrating different scientific and extra-scientific insights; its aim is to contribute to both societal and scientific progress; integration is the cognitive operation of establishing a novel, hitherto non-existent connection between the distinct epistemic, social-organizational, and communicative entities that make up the given problem context." In these terms, Transdisciplinary Research (TDR) aims to enable mutual learning processes between science and society.

There are various frameworks for conducting transdisciplinary research. Here, we focus on the conceptual, ideal-typical model of transdisciplinarity proposed by the authors of [61]. This model's basic assumption is that "developing solutions for societal problems always means and requires linking these problems to gaps in the existing bodies of knowledge, that is, to scientific problems. Seemingly self-evident, this proposition, however, allows us to conceptualize the contributions to societal and scientific progress as the two epistemic ends of a single research dynamic." [61] (p. 4). This general argument is applicable to and highly relevant for ES research. As described above, the ES concept and its scientific pillars are contested-at least when it comes to conflicting worldviews and systems of values within. Additionally, the basis for science-driven assessments is not always perceived to be sufficient. Recent efforts such as IPBES, the TEEB-studies at different scales, or European knowledge brokers such as biodiversity knowledge (KNEU) or EKLIPSE-The European Mechanism for Supporting Better Decision Making on Biodiversity and Ecosystem Services, indicate a need for system knowledge in the field of biodiversity and ecosystem services. They should support a better understanding of processes and the interlinkages between ecosystems and society for the 'production' and 'consumption' of ES. Some years ago, 
the debate on the so-called 'post 2015-targets' for biodiversity showed that there is also a need for knowledge that supports defining objectives for conservation and sustainable management of ES [64]. In such a situation, the ways and means of reaching those objectives may be highly controversial. In the end, the call for a sound consideration of trade-offs within different policy strategies, or between various actions, suggests that transformation knowledge is needed [65].

Against this background, the problem-orientation of TDR is able to give new impulses to the ES concept as a boundary concept. In Figure 3, an exemplary TDR process for working with ES is illustrated. In the upper part of the figure, the main function of ES as boundary object comes to the fore: a boundary object is the starting point for formulating a transdisciplinary epistemic object that relates to a joint problem. Thus, it demands to be able to relate a real-world problem-for example, searching for ways to solve conflicts between agricultural production and conservation in a certain area-to scientific research questions, such as the causes and effects of changes in species distribution. If using ES as a boundary concept, a possible intersection in this example could be the analysis of drivers and pressures for ES changes. This example shows that in TDR-ideal-typically-a joint problem is constituted that originates neither solely in society nor solely in science (cf. [61] (p. 4ff.). With this starting point, new integrated knowledge can be produced in order to develop (partial) answers to the initial-societal and scientific questions (path in the middle of the Figure 3). Participatory elements in combination with strong methods for relating scientific and non-scientific knowledge, such as focus groups, stakeholder workshops, the Delphi method, or integration through the formation of interdisciplinary teams are at the core $[66,67]$. While multi- or interdisciplinary efforts focus mainly on the knowledge production and often result in scientific papers with limited outreach regarding the initial real-world problem, TDR foresees a further step: for serving society through research, applications, and communication, the transdisciplinary integration (lower part of the Figure 3) is crucial. The knowledge and the (partial) answers gained are to be evaluated against the background of the joint problem and the initial questions. Then, two kinds of 'products' can be derived: on the one hand, there is a need for products that are applicable in practice, for example, decision-support tools, guidelines, and learning videos; on the other hand, scientific contributions are derived that are innovative for the scientific praxis. Examples mentioned in Figure 3 (model of social-ecological systems, SES) show that those scientific contributions go beyond disciplinary discourses. This example is mentioned here, because ES are a kind of scientific eye-opener for a better understanding of the societal relations to nature $[2,68]$.

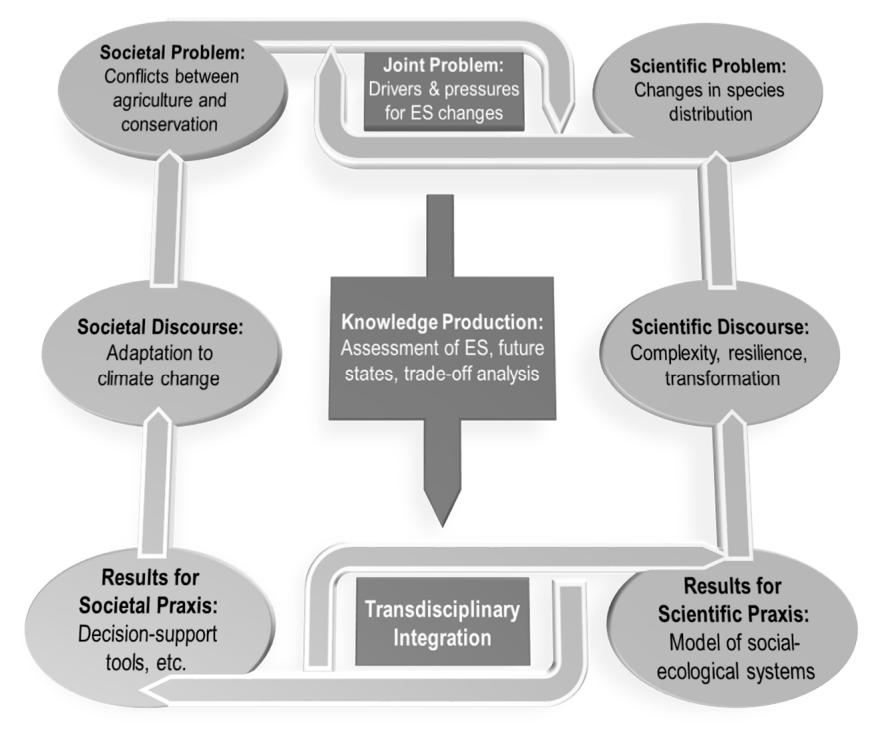

Figure 3. Framing ES research as a Transdisciplinary Research (TDR) process, based on the ideal-typical model for TDR by [61] (p. 5). 


\section{Rethinking Ecosystem Services Research: Implications and Requirements towards a Social-Ecological Application}

In the final section, we provide and discuss implications of and requirements derived from the analysis of ES research presented above for the further development of social-ecological approaches. First, there is a need for identifying and applying empirical and analytical methods and approaches that foster a more systematic and comprehensive understanding of the interdependencies between nature and society. Current forms and applications of (ES or impact) assessments often fail to sufficiently account for those interdependencies. This is particularly true for capturing the dynamics of ES supply and demand [2]. In this regard, we see great potential for bridging the ES Cascade Model [12] and the Stairways Model [21]; to go beyond a linear model of service provision and to analyse more carefully the identification of ecosystem functions, services, and benefits in the light of respective societal processes (e.g., migration and urbanization) and the boundary negotiations involved. Monetary valuation, for example, can be strictly rejected by several cultures and this conflict between monetary and anti-monetary, not only non-monetary valuation, creates strong boundary negotiations which may lead to a refusal of the concept of ES itself [22]. The introduction of ESPs and the notion that their identification is essentially part of and the result of complex social processes more explicitly links the observed (dynamics in) ecosystem stocks and flows to political and societal dynamics. Here, transdisciplinary approaches are essential to identify and analyse the complex interlinkages between societal and natural processes. If we take TDR seriously, as illustrated in Figure 3, there is a need to integrate ES research more explicitly into wider frameworks or larger concepts such as SES (see [2], but also [65,69,70]) or socioeconomic metabolism [51,71]) in order to capture the intended and unintended activities from society on nature that might influence ES provisioning. This promises a better consideration of the social-ecological dynamics of ecosystem services, namely the functional relation between ES supply and demand influencing each other [2].

Moreover, a better link of ES research with other approaches may also improve their uptake within ongoing or future international research programmes, such as Future Earth. Such approaches are fostering and calling for the co-design and co-production of knowledge-by means of interand transdisciplinary methods-to provide scientifically sound input for a transformation towards sustainability [60]. Here, ES research may play a pivotal role, for example, to determine options and constraints for further land use and biomass production.

Thus, the ongoing debates on the further development of the conceptual framework used in the IPBES process, in particular with respect to the different perceptions of nature as well as appropriate ways of value articulating, can and should be supported by a systematic application of inter- and transdisciplinary methods. There is a vast variety of useful entry points or opportunities to demonstrate the added value of inter- and transdisciplinary research methods and the need for their further development. Many policies and other regulatory frameworks at all levels are dealing either directly (e.g., via research frameworks such as the EU Horizon 2020 or similar) or indirectly with ES research, by making ES-related assessments (e.g., the UK National Ecosystem Assessment, NEA) compulsory or at least part of the process of designing and implementing respective policies.

There are tremendous governance challenges resulting from trade-offs between ecosystem services or land-use conflicts which can be identified and made transparent through ES research. In particular, transdisciplinary research can help create 'sustainable' spaces or fora for communication and negotiation. If land use and biomass production become more important in the future, interand transdisciplinary ES research can help to account for and deal with such trade-offs and land-use conflicts by making different normative values and different monetary and non-monetary benefits more explicit, and to address the ESPs as well as the biophysical and societal constraints of land use (e.g., the distributional effects and the power relations behind them).

Finally, one should also reflect on the discrepancy between a concept that inherently hinges on inter- and transdisciplinary research approaches and 'thinking' as well as respective forms of 
collaboration, and an academic system that is (still) rather cherishing disciplinarily publications and 'rigorous' research.

Acknowledgments: Christian Schleyer and Christoph Görg acknowledge funding by the European Union (7th Framework Program; Grant Agreement no: 308428).

Author Contributions: Christian Schleyer had the idea and developed the concept of the paper. Further, he was responsible for the introduction and summarised the scientific discourse on the socio-ecological nature of the ES concept. Christoph Görg was responsible for summarising the arguments why the ES concept should be seen as a boundary concept and for establishing the link between the ES concept and the colonisation of nature approach. Alexandra Lux was responsible for the background on transdisciplinary research and Marion Mehring provided the arguments for including it into ES research. All authors contributed to the discussion equally. Christian Schleyer was responsible for the overall writing process of the paper.

Conflicts of Interest: The authors declare no conflict of interest. The founding sponsors had no role in the design of the study; in the collection, analyses, or interpretation of data; in the writing of the manuscript, and in the decision to publish the results.

\section{References}

1. Millennium Ecosystem Assessment. Ecosystems and Human Well-Being. A Framework for Assessment; Island Press: Washington, DC, USA, 2005.

2. Mehring, M.; Zajonz, U.; Hummel, D. Social-Ecological Dynamics of Ecosystem Services: The Functional Relation Between Supply and Demand—Evidence from Socotra Archipelago, Yemen and the Sahel Region, West Africa. Sustainability 2017, under review.

3. Von Becker, E.; Jahn, T. (Eds.) Soziale Ökologie: Grundzüge einer Wissenschaft von den Gesellschaftlichen Naturverhältnissen; Campus: Frankfurt/M., Germany, 2006.

4. Haberl, H.; Fischer-Kowalski, M.; Krausmann, F.; Winiwarter, V. (Eds.) Social Ecology. Society-Nature Relations across Time and Space; Springer International: Basel, Switzerland, 2016.

5. Kramm, J.; Pichler, M.; Schaffartzik, A.; Zimmermann, M. Societal relations to nature in times of crisis-Social ecology's contributions to interdisciplinary sustainability studies. Sustainability 2017, under review.

6. Schröter, M.; van der Zanden, E.H.; van Oudenhoven, A.P.E.; Remme, R.P.; Serna-Chavez, H.M.; De Groot, R.S.; Opdam, P. Ecosystem services as a contested concept: A synthesis of critique and counter-arguments. Conserv. Lett. 2014, 7, 514-523. [CrossRef]

7. Boyd, J.; Banzhaf, S. What are ecosystem services? The need for standardized environment accounting units. Ecol. Econ. 2007, 63, 616-626. [CrossRef]

8. Fisher, B.; Turner, R.K.; Morling, P. Defining and classifying ecosystem services for decision-making. Ecol. Econ. 2009, 68, 643-653. [CrossRef]

9. Barkmann, J.; Glenk, K.; Keil, A.; Leemhuis, C.; Dietrich, N.; Gerold, G.; Marggraf, R. Confronting unfamiliarity with ecosystem functions: The case for an ecosystem service approach to environmental valuation with stated preference methods. Ecol. Econ. 2008, 65, 48-62. [CrossRef]

10. Lamarque, P.; Tappeiner, U.; Turner, C.; Steinbacher, M.; Bardgett, R.D.; Szukics, U.; Schermer, M.; Lavorel, S. Stakeholder perceptions of grassland ecosystem services in relation to knowledge on soil fertility and biodiversity. Reg. Environ. Chang. 2011, 11, 791-804. [CrossRef]

11. Nahlik, A.M.; Kentula, M.E.; Fennessy, M.S.; Landers, D.H. Where is the consensus? A proposed foundation for moving ecosystem service concepts into practice. Ecol. Econ. 2012, 77, 27-35. [CrossRef]

12. Potschin, M.; Haines-Young, R. Ecosystem Services: Exploring a geographical perspective. Prog. Phys. Geog. 2011, 35, 575-594. [CrossRef]

13. Menzel, S.; Teng, J. Ecosystem services as a stakeholder-driven concept for conservation science. Conserv. Biol. 2010, 24, 907-909. [CrossRef] [PubMed]

14. Chan, K.M.; Guerry, A.D.; Balvanera, P.; Klain, S.; Satterfield, T.; Basurto, X.; Bostrom, A.; Chuenpagdee, R.; Gould, R.; Halpern, B.S.; et al. Where are Cultural and Social in Ecosystem Services? A Framework for Constructive Engagement. BioScience 2012, 62, 744-756.

15. Bieling, C.; Plieninger, T. Recording manifestations of cultural ecosystem services in the landscape. Landsc. Res. 2013, 38, 649-667. [CrossRef]

16. Kosoy, N.; Corbera, E. Payments for ecosystem services as commodity fetishism. Ecol. Econ. 2010, 69, 1228-1236. [CrossRef] 
17. McAfee, K.; Shapiro, E. Payments for ecosystem services in Mexico: Nature, neoliberalism, social movements, and the state. Ann. Assoc. Am. Geogr. 2010, 100, 579-599. [CrossRef]

18. McCauley, D. Selling out on nature. Nature 2006, 443, 27-28. [CrossRef] [PubMed]

19. Görg, C.; Aicher, C. Ökosystemdienstleistungen-Zwischen Natur und Gesellschaft. Anforderungen an eine inter- und transdisziplinäre Forschung aus Sicht der Sozialwissenschaften. In Berlin-Brandenburgische Akademie der Wissenschaften, Berichte und Abhandlungen; De Gruyter-Akademie Verlag: Berlin, Germany, 2014; Volume 16, pp. 35-58.

20. Loft, L.; Lux, A.; Jahn, T. A Social-Ecological Perspective on Ecosystem Services. In Routledge Handbook of Ecosystem Services; Potschin, M., Haines-Young, R., Fish, R., Eds.; Routledge: London, UK; New York, NY, USA, 2016; pp. 88-92.

21. Spangenberg, J.H.; Von Haaren, C.; Settele, J. The ecosystem service cascade: Further developing the metaphor. Integrating societal processes to accommodate social processes and planning, and the case of bioenergy. Ecol. Econ. 2014, 104, 22-32. [CrossRef]

22. Spangenberg, J.H.; Görg, C.; Truong, D.T.; Tekken, V.; Bustamante, J.V.; Settele, J. Provision of ecosystem services is determined by human agency, not ecosystem functions. Four case studies. Int. J. Biodivers. Sci. Ecosyst. Serv. Manag. 2014, 10, 40-53. [CrossRef]

23. Hausknost, D.; Gaube, V.; Haas, W.; Smetschka, B.; Schmid, M.; Lutz, J.; Singh, S.J. “Society can't move so much as a chair!" Systems, Structures and Actors in Social Ecology. In Social Ecology: Society-Nature Relations across Time and Space; Haberl, H., Fischer-Kowalski, M., Krausmann, F., Winiwarter, V., Eds.; Springer: Dordrecht, The Netherlands, 2016; pp. 125-147.

24. Huntsinger, L.; Oviedo, J.L. Ecosystem services are socialecological services in a traditional pastoral system: The case of California's mediterranean rangelands. Ecol. Soc. 2014, 19, 8. [CrossRef]

25. Plieninger, T.; van der Horst, D.; Schleyer, C.; Bieling, C. Sustaining ecosystem services in cultural landscapes. Ecol. Soc. 2014, 19, 59. [CrossRef]

26. Comberti, C.; Thornton, T.F.; Wylliede Echeverria, V.; Patterson, T. Ecosystem services or services to ecosystems? Valuing cultivation and reciprocal relationships between humans and ecosystems. Glob. Environ. Chang. 2015, 34, 247-262. [CrossRef]

27. Palomo, I.; Felipe-Lucia, M.R.; Bennett, E.M.; Martín-López, B.; Pascual, U. Disentangling the Pathways and Effects of Ecosystem Service Co-Production. Adv. Ecol. Res. 2016, 54, 245-283. [CrossRef]

28. Fischer-Kowalski, M.; Erb, K.-H. Core Concepts and Heuristics. In Social Ecology: Society-Nature Relations across Time and Space; Haberl, H., Fischer-Kowalski, M., Krausmann, F., Winiwarter, V., Eds.; Springer: Dordrecht, The Netherlands, 2016; pp. 29-62.

29. Abson, D.J.; von Wehrden, H.; Baumgärtner, S.; Fischer, J.; Hanspach, J.; Härdtle, W.; Heinrichs, H.; Klein, A.M.; Lang, D.J.; Martens, P.; et al. Ecosystem services as a boundary object for sustainability. Ecol. Econ. 2014, 103, 29-37. [CrossRef]

30. Potschin, M.; Haines-Young, R. Defining and measuring ecosystem services. In Routledge Handbook of Ecosystem Services; Potschin, M., Haines-Young, R., Fish, R., Eds.; Routledge: London, UK; New York, NY, USA, 2016; pp. 25-44.

31. Hauck, J.; Görg, C.; Jax, K.; Varjopurob, R.; Ratamäki, O. Benefits and limitations of the ecosystem services concept in environmental policy and decision making-Some stakeholder perspectives. Environ. Sci. Policy 2013, 25, 13-21. [CrossRef]

32. Jordan, A.J.; Russel, D. Embedding the concept of ecosystem services? The utilisation of ecological knowledge in different policy venues. Environ. Plan. C Gov. Policy 2014, 32, 192-207. [CrossRef]

33. Jasanoff, S. States of Knowledge: The Co-Production of Science and Social Order; Routledge: London, UK; New York, NY, USA, 2004.

34. Kull, C.A.; Arnauld de Sartre, X.; Castro-Larrañaga, M. The political ecology of ecosystem services. Geoforum 2015, 61, 122-134. [CrossRef]

35. Kolinjivadi, V.; Van Hecken, G.; Rodríguez de Francisco, J.C.; Pelenc, J.; Kosoy, N. As a lock to a key? Why science is more than just an instrument to pay for nature's services. Curr. Opin. Environ. Sustain. 2017, 26-27, 1-6. [CrossRef]

36. Hausknost, D.; Grima, N.; Singh, S.J. The political dimensions of Payments for Ecosystem Services (PES): Cascade or stairway? Ecol. Econ. 2017, 131, 109-118. [CrossRef] 
37. Tancoigne, E.; Barbier, M.; Cointet, J.-P.; Richard, G. The place of agricultural sciences in the literature on ecosystem services. Ecosyst. Serv. 2014, 10, 35-48. [CrossRef]

38. Alison, G. Power Ecosystem services and agriculture: Tradeoffs and synergies. Philos. Trans. R. Soc. B 2010, 365, 2959-2971. [CrossRef]

39. Laurans, Y.; Rankovic, A.; Billé, R.; Pirard, R.; Mermet, L. Use of ecosystem services economic valuation for decision making: Questioning a literature blindspot. J. Environ. Manag. 2013, 119, 208-219. [CrossRef] [PubMed]

40. Gómez-Baggethun, E.; Ruiz-Perez, M. Economic valuation and the commodification of ecosystem services. Prog. Phys. Geogr. 2011, 35, 613-628. [CrossRef]

41. Norgaard, R.B. Ecosystem services: From eye-opening metaphor to complexity blinder. Ecol. Econ. 2010, 69, 1219-1227. [CrossRef]

42. The Economics of Ecosystem Services and Biodiversity (TEEB). The Economics of Ecosystems and Biodiversity: Ecological and Economic Foundations; Kumar, P., Ed.; Earthscan: London, UK; Washington, DC, USA, 2010.

43. Díaz, S.; Demissew, S.; Carabias, J.; Joly, C.; Lonsdale, M.; Ash, N.; Larigauderie, A.; Adhikari, J.R.; Arico, S.; Báldi, A.; et al. The IPBES Conceptual Framework-connecting nature and people. Curr. Opin. Environ. Sustain. 2015, 14, 1-16. [CrossRef]

44. Seppelt, R.; Fath, B.; Burkhard, B.; Fisher, J.L.; Grêt-Regamey, A.; Lautenbach, S.; Pert, P.; Hotes, S.; Spangenberg, J.H.; Verburg, P.H.; et al. Form follows function? Proposing a blueprint for ecosystem service assessments based on reviews and case studies. Ecol. Indic. 2012, 21, 145-154. [CrossRef]

45. Hauck, J.; Görg, C.; Varjopuro, R.; Ratamäki, O.; Maes, J.; Wittmer, H.; Jax, K. "Maps have an air of authority": Potentials and challenges of ecosystem service maps in decision making at different levels of decision making. Ecosyst. Serv. 2013, 4, 25-32. [CrossRef]

46. Carmen, E.; Young, J.; Watt, A. Knowledge Needs for the Operationalization of the Concept of Ecosystem Services (ES) and Natural Capital (NC); EU FP7 OpenNESS Project Deliverable 2.3; European Commission FP7: Brussels, Belgium, 2015.

47. Dempsey, J.; Robertson, M.M. Ecosystem Services: Tensions, impurities and pints of engagement within neoliberalism. Prog. Hum. Geogr. 2012, 36, 758-779. [CrossRef]

48. Barnaud, C.; Antona, M. Deconstructing ecosystem services: Uncertainties and controversies around a socially constructed concept. Geoforum 2014, 56, 113-123. [CrossRef]

49. Gómez-Baggethun, E.; De Groot, R.; Lomas, P.L.; Montes, C. The history of ecosystem services in economic theory and practice: From early notions to markets and payment schemes. Ecol. Econ. 2010, 69, 1209-1218. [CrossRef]

50. Haines-Young, R.; Potschin, M. Common International Classification of Ecosystem Services (CICES): Consultation on Version 4, August-December 2012. EEA Framework Contract No. EEA/IEA/09/003, 2013. Available online: www.cices.euorwww.nottingham.ac.uk/cem (accessed on 27 December 2016).

51. Fischer-Kowalski, M.; Haberl, H. Sustainable Development: Socio-Economic Metabolism and Colonization of Nature. Int. Soc. Sci. J. 1998, 158, 573-587. [CrossRef]

52. Haberl, H.; Erb, K.-H.; Krausmann, F.; Gaube, V.; Bondeau, A.; Plutzar, C.; Gingrich, S.; Lucht, W.; Fischer-Kowalski, M. Quantifying and mapping the human appropriation of net primary production in earth's terrestrial ecosystems. Proc. Natl. Acad. Sic. USA 2007, 104, 12942-12947. [CrossRef] [PubMed]

53. Fischer-Kowalski, M.; Weisz, H. Society as Hybrid between Material and Symbolic Realms. Toward a Theoretical Framework of Society-Nature Interrelation. Adv. Hum. Ecol. 1999, 8, 215-251.

54. Cardinale, B.J.; Duffy, J.E.; Gonzalez, A.; Hooper, D.U.; Perrings, C.; Venail, P.; Narwani, A.; Mace, G.M.; Tilman, D.; Wardle, D.A.; et al. Biodiversity loss and its impact on humanity. Nature 2012, 486, 59-67. [CrossRef] [PubMed]

55. Marx, K. Capital; Vintage: New York, NY, USA, 1981; Volume I.

56. Foster, J.B. Marx's Theory of Metabolic Rift: Classical Foundations for Environmental Sociology. Am. J. Sociol. 1999, 105, 381. [CrossRef]

57. Moore, J.W. Transcending the Metabolic Rift: Towards a Theory of Crises in the Capitalist World-Ecology. J. Peasant Stud. 2011, 38, 1-46. [CrossRef]

58. Polanyi, K. The Great Transformation; Farrar \& Rinehart: New York, NY, USA, 1944.

59. Marx, K. Capital; Penguin Books: London, UK, 1990 [1867]; Volume I. 
60. Görg, C.; Brand, U.; Haberl, H.; Hummel, D.; Jahn, T.; Liehr, S. Challenges for Social-Ecological Transformations. Contributions from Social and Political Ecology. Sustainability 2017, accepted.

61. Jahn, T.; Bergmann, M.; Keil, F. Transdisciplinarity: Between mainstreaming and marginalization. Ecol. Econ. 2012, 79, 1-10. [CrossRef]

62. Hirsch Hadorn, G.; Bradley, D.; Pohl, C.; Rist, S.; Wiesmann, U. Implications of Transdisciplinarity for Sustainability Research. Ecol. Econ. 2006, 60, 119-128. [CrossRef]

63. Lang, D.J.; Wiek, A.; Bergmann, M.; Stauffacher, M.; Martens, P.; Moll, P.; Swilling, M.; Thomas, C.J. Transdisciplinary research in sustainability science: Practice, principles, and challenges. Sustain. Sci. 2012, 7, 25-43. [CrossRef]

64. Mace, G.M.; Cramer, W.; Díaz, S.; Faith, D.P.; Larigauderie, A.; Le Prestre, P.; Palmer, M.; Perrings, C.; Scholes, R.J.; Walpole, M.; et al. Biodiversity targets after 2010. Curr. Opin. Environ. Sustain. 2010, 2, 3-8. [CrossRef]

65. Carpenter, S.R.; Folke, C.; Norström, A.; Olsson, O.; Schultz, L.; Agarwal, B.; Balvanera, P.; Campbell, B.; Castilla, J.C.; Cramer, W.; et al. Program on ecosystem change and society: An international research strategy for integrated social-ecological systems. Curr. Opin. Environ. Sustain. 2012, 4, 1-5. [CrossRef]

66. Bergmann, M.; Jahn, T.; Knobloch, T.; Krohn, W.; Pohl, C.; Schramm, E. Methods for Transdisciplinary Research. A Primer for Practice; Campus Verlag: Frankfurt/M., Germany; New York, NY, USA, 2012.

67. Daedlow, K.; Podhora, A.; Winkelmann, M.; Kopfmüller, J.; Walz, R.; Helming, K. Socially responsible research processes for sustainability transformation: An integrated assessment framework. Curr. Opin. Environ. Sustain. 2016, 23, 1-11. [CrossRef]

68. Hummel, D.; Jahn, T.; Keil, F.; Liehr, S.; Stieß, I. Social Ecology as Critical, Transdisciplinary Science-Conceptualizing, Analyzing, and Shaping Societal Relations to Nature. Sustainability 2017, under review.

69. Ostrom, E. A General Framework for Analyzing the Sustainability of Social-Ecological-Systems. Science 2009, 325, 419-422. [CrossRef] [PubMed]

70. Folke, C. Resilience: The emergence of a perspective for social-ecological systems analyses. Glob. Environ. Chang. 2006, 16, 253-267. [CrossRef]

71. Haberl, H.; Wiedenhofer, D.; Erb, K.-H.; Görg, C.; Krausmann, F. Interrelations between material stocks, flows and services: A new approach to tackle the decoupling conundrum. Sustainability 2017, under review. 